\title{
Efficiency assessment of public higher education with the application of Data Envelopment Analysis: The evidence from Poland
}

\author{
Michał Pietrzak, WULS-SGGW, michal_pietrzak@sggw.pl \\ Piotr Pietrzak, WULS-SGGW, piotr_pietrzak@sggw.pl \\ Joanna Baran, WULS-SGGW, joanna_baran@sggw.pl
}

\begin{abstract}
Higher education is a form of a merit good. This is why governments usually support the delivery of this good. However, one could doubt the efficiency of such solution. How well do public higher education institutions (HEIs) do their job? How to measure their performance? This paper discusses these issues. First, we discuss the problem of defining and measuring efficiency in the case of publicly held HEIs with particular emphasis put on the Data Envelopment Analysis (DEA) method. Secondly, we present the results of our empirical investigation of efficiency assessed using the DEA method conducted on the sample of 33 Poland faculties specialized in social sciences. We use Charnes-Cooper-Rhodes (CCR) output oriented model with two inputs and three outputs. Next, we present some important differences in efficiency of those faculties. We also define benchmarks for inefficient HEIs and quantify the gaps to be fulfilled by them in order to become efficient. Finally, we pinpoint the directions of further research.
\end{abstract}

Keywords: higher education institutions, efficiency, Data Envelopment Analysis (DEA), public sector

\section{Introduction}

The education system, particularly on the highest level, is an important source of knowledge in developed countries. Delivering higher education creates positive externalities, which means that it offers benefits to the economy that exceed those to any individual who consumes it. Benefits from education go not only to a graduate and their family, but also to third parties: through higher productivity, greater satisfaction of living in a society with democratic institutions, lower crime rates, lower unemployment compensation and public health costs and many others (Begg Fischer, \& Dornbusch, 2014, McMahon, 1982). This is why the governments are often engaged in the higher education sector. However, the engagement of a government in the higher education differs across regions and countries. In the USA, higher education is financed in prevailing proportions privately, but in European countries the proportions are reverse - higher education institutions (HEIs) are financed mainly (80 to 95\%) publicly from governmental budgets (Paliszkiewicz, 2010).

The scale of governmental engagement in higher education is an interesting issue. On the one hand, such educational services are considered merit goods which create externalities, but on the other hand, the public sector does not produce better or more efficient goods (Bowden \& Bowden 2002). Indeed, public bureaus or agencies are usually seen as achieving inferior 
performance in comparison to the business sector. The contemporary societies create an increasing pressure on public organizations to be more elastic, entrepreneurial, and parsimonial entities (Ansoff, 1979). This pressure is embodied in the New Public Management (NPM) concept. According to NPM, the public sector organizations have to strive for the efficiency analogous to the business counterparts, particularly by implementing competitive mechanisms, customer orientation, decentralization, performance measurement and strategic management. The NPM has been applied recently to higher education institutions, mainly in European countries (Schimank, 2005; Tahar, 2013; Wilkesman \& Schmid, 2012). Consequently, the methods and techniques such as: setting targets of efficiency and effectiveness, benchmarking, performance measurement etc. are growing in popularity with higher education institutions (Parker, 2012).

The purpose of this paper is twofold. The first one is to discuss the problem of the efficiency of public universities and to present how it can be measured. The second one is to empirically verify the differences in efficiency of faculties of social sciences in Poland and to identify possible improvements.

\section{The problem of efficiency measurement in the public higher education}

Ansoff (1979) made a distinction between two types of environment serving organizations: firms and not profit-oriented organizations, which differ in strategic behaviour. The latter could by further divided into public not-for-profit organizations (government bureaus and agencies) and private not-for-profit organizations i.e. nonprofits (Carroll, 2004). One can find every of these three types of organizations engaged in the higher education, however in this paper we are concerned with publicly held institutions. Recently, there has been an increasing interest in performance measurement in public bureaus and agencies (Byrson, J. M., \& Alston, F. K. 2011; Niven, 2008).

But what does efficiency really mean in the case of the public sector, particularly the public universities? How could it be measured? What are the objectives and the efficiency criteria? Who defines the objectives and the criteria? Who is the owner of a bureau or an agency? According to Carroll (2004), in the general sense, taxpayers should be considered as the owner of public organizations. Legislators are the taxpayers' representatives. Legislators could defend the interest of the latter through their decisions on the amount of funds to allocate for projects and programs of each public organization (Carroll, 2004). As Taylor and Baines (2012) observed, the universities in the UK have become increasingly interested in performance management methods, for example in the Balanced Scorecard. Pietrzak (2014) and Pietrzak Paliszkiewicz, \& Klepacki (2015) gave an evidence of how the Balanced Scorecard could be used in strategy communication and in performance management at the example of one of the big Polish universities. Balanced Scorecard is a very useful method of translating a strategy into measurable targets and actionable initiatives (Kaplan \& Norton, 2008). However, this role implies that it should be specifically designed for every individual case, because the strategy should be unique for any organization. Consequently, the Balanced Scorecard based on many uniquely dedicated metrics and indicators is a helpful tool for the strategic management for the executives of a higher education institution, but it does not seem to be very helpful for the legislators in performance controlling of a number of universities. In this case, a method that allows a direct efficiency comparison between public organizations could be more useful. 
Considering the functionality of public bureaus and agencies' benchmarking, it is worth paying attention to the Data Envelopment Analysis (DEA) method. This is because DEA allows for a relative appraisal of the efficiency of studied objects. Thus, efficient benchmarks for inefficient entities can be defined. Accordingly, gaps are identified in a quantitative manner. These gaps should be fulfilled if any inefficient object wants to become efficient. Another advantage of the DEA method is its ability to take into account many outputs and inputs simultaneously. This functionality is very important in universities assessment because of many desirable results and multiple production factors engaged.

The DEA occupies an important place in the comparative efficiency studies in the public sector worldwide, for example in the health care (Färe, Grosskopf, Lindgren, \& Roos, 1992; Hollingsworth, Dawson, \& Maniadakis, 1999; Jacobs, 2001), in the military entities (Sun, 2004) and, last but not least, in higher education institutions (Bates, 1993; Thanassoulis \& Dunstan, 1994). Examples of DEA application around the world are described in literature by Worthington (2001), Taylor and Harris (2004), Baran, Pietrzak, M., \& Pietrzak, P., (2015), and Mikušová (2015). The existing studies on the efficiency of higher education institutions have been based mainly on country-specific data (Wolszczak-Derlacz \& Parteka, 2011). Table 1 provides a summary of selected empirical studies from the last two decades, which are based on the DEA methodology in assessing higher education efficiency.

In the UK, the issues of higher education efficiency receive a lot of attention, thus providing many instances of DEA application for the assessment of higher education productivity (Nazarko \& Šaparauskas, 2014). Athanassopoulos and Shale (1997) proposed the concepts of cost and outcome efficiency. DEA was used in their research to assess these two types of efficiency. Their study of 45 universities in the UK revealed a subset of six organizations that showed satisfactory performance across alternative efficiency tests (Athanassopoulos \& Shale, 1997). Another British example of DEA application is Johnes (2006) examination of the efficiency of more than 100 universities in the period 2000-2001 According to Johnes (2006), the technical and scale efficiency in the UK higher education sector appeared to be high on average. The quality and the quantity of undergraduate degrees, the quantity of postgraduate degrees and research were significant outputs in the UK higher education production process (Johnes, 2006).

From 1997-1999, Warning (2004) examined the efficiency of 73 universities in Germany using the DEA method. Warning (2004) results indicated that universities were better in teaching than in research, and they were also better in natural sciences than in social sciences. The results also provided evidence that universities in Germany differed regarding their level of efficiency and the underlying effects (Warning, 2004).

Abramo, D'Angelo and Pugini (2008) presented a methodology of measuring the technical efficiency of research activities. It was based on the application of DEA to bibliometric data on the Italian university system. Different input values (research personnel by level and extra funding) and output values (quantity, quality and level of contribution to actual scientific publications) were considered (Abramo, D'Angelo, \& Pugini 2008).

In Thailand, the relative efficiency in the production of research and teaching from 2003-2006 was analysed. Kantabutra and Tang (2010) xamined the difference in performance between two types of public universities: the government universities and the autonomous universities. The results indicated that the autonomous universities outperformed the government universities in terms of research efficiency (Kantabutra \& Tang, 2010). 
Table 1. Selective empirical studies using DEA to evaluate the efficiency of higher education institutions

\begin{tabular}{|c|c|c|c|}
\hline Reference* & $\begin{array}{c}\text { Country/ Sample of HEIs/ } \\
\text { Period of study }\end{array}$ & Inputs & Outputs \\
\hline $\begin{array}{l}\text { Athanassopoulos } \\
\text { and Shale (1997) }\end{array}$ & $\begin{array}{c}\text { UK } \\
(45 \text { universities }) \\
1992-93\end{array}$ & $\begin{array}{l}\text { number of undergraduates, postgraduates and academic staff, mean A- } \\
\text { level entry score over the last three years, } \\
\text { research income, expenditure on library and computing services }\end{array}$ & $\begin{array}{l}\text { number of successful leavers, number of higher degrees } \\
\text { awarded, weighted research rating }\end{array}$ \\
\hline Warning (2004) & $\begin{array}{c}\text { Germany } \\
\text { (73 universities) } \\
1997-99\end{array}$ & expenditure on personnel, other expenditures & $\begin{array}{l}\text { SSCI (Social Science Citation Index) publications, SCI } \\
\text { (Science Citation Index) publications, SSCI graduates, SCI } \\
\text { graduates }\end{array}$ \\
\hline Johnes (2006) & $\begin{array}{l}\text { England } \\
(109 \text { universities) } \\
2000-01\end{array}$ & $\begin{array}{l}\text { number of FTE (Full Time Equivalent) undergraduate students studying } \\
\text { for a first degree multiplied by the average A-level points for first year } \\
\text { full-time undergraduate students, number of FTE postgraduate students, } \\
\text { number of full-time academic staff, expenditure on central libraries and } \\
\text { information services, and on central computer and computer networks, } \\
\text { expenditure on central administration and central services }\end{array}$ & $\begin{array}{l}\text { number of first degrees awarded weighted by degree } \\
\text { classification, number of higher degrees awarded, value of } \\
\text { recurrent grant for research awarded by the Higher } \\
\text { Education Funding Council for England }\end{array}$ \\
\hline $\begin{array}{c}\text { Abramo, } \\
\text { D'Angelo and } \\
\text { Pugini (2008) }\end{array}$ & $\begin{array}{l}\text { Italy } \\
(64 \text { universities) } \\
2001-03\end{array}$ & $\begin{array}{l}\text { number of full professors, number of associate professors } \\
\text { number of research scientists, PRIN funding for research }\end{array}$ & $\begin{array}{l}\text { number of publications, contribution to publications } \\
\text { scientific strength }\end{array}$ \\
\hline $\begin{array}{l}\text { Kantabutra and } \\
\text { Tang (2010) }\end{array}$ & $\begin{array}{l}\text { Thailand } \\
\text { (267 faculties) } \\
2003-06\end{array}$ & $\begin{array}{l}\text { For TEM (Teaching Efficiency Model): annual operating budget, number } \\
\text { of academic staff, number of non-academic staff } \\
\text { For REM (Research Efficiency Model): amount of internal and external } \\
\text { research found }\end{array}$ & $\begin{array}{l}\text { For TEM (Teaching Efficiency Model): number of graduates } \\
\text { at the undergraduate/ master degree levels, employment rate } \\
\text { For REM (Research Efficiency Model): } \\
\text { number of publications in internationally/ nationally } \\
\text { refereed journals, number of PhD degrees }\end{array}$ \\
\hline $\begin{array}{l}\text { Monafared and } \\
\text { Safi (2011) }\end{array}$ & $\begin{array}{l}\text { Iran } \\
(27 \text { universities }) \\
1999\end{array}$ & $\begin{array}{l}\text { For TEM and CEM (Teaching Efficiency Model, Cost Efficiency } \\
\text { Model): staff per student, faculty members per major, faculty members } \\
\text { positions, books per student } \\
\text { material procurement cost, capital expenditure } \\
\text { For REM (Research Efficiency Model): staff per student, faculty } \\
\text { members per major, faculty members' positions, teaching load, books per } \\
\text { student, material procurement cost, capital expenditure }\end{array}$ & $\begin{array}{l}\text { For TEM (Teaching Efficiency Model): students per faculty, } \\
\text { teaching load, faculty receivable from extra lecturing hours } \\
\text { For REM (Research Efficiency Model): external contracts to } \\
\text { total, } \\
\text { For CEM (Cost Efficiency Model): students per faculty, } \\
\text { teaching load, external contracts to total }\end{array}$ \\
\hline $\begin{array}{l}\text { Wolszczak- } \\
\text { Derlacz and } \\
\text { Parteka (2011) }\end{array}$ & $\begin{array}{l}\text { Austria, Finland, Germany, } \\
\text { Italy, Poland, UK and } \\
\text { Switzerland (259 universities) } \\
2001-05\end{array}$ & total academic staff, total number of students, total revenues & number of graduations, number of scientific publications \\
\hline
\end{tabular}

Studies are presented in chronological order.

Source: own elaboration based on the referred literature. 
In 1999, 27 Iran universities were studied from the perspective of their efficiency. Monafared and Safi (2011) provided an analysis on the importance of the stakeholder's perspective on the structure of DEA and the variations of efficiency results. They examined efficiency from three different perspectives of importance, i.e. teaching quality, research productivity, and cost efficiency by using available data. Monafared and Safi (2011) noted that the data used in their experiments was over 10 years old, whereas in recent years, the higher education institutions in Iran had undergone dramatic changes (Monafared \& Safi, 2011).

Wolszczak-Derlacz and Parteka (2011) examined efficiency and its determinants in a set of universities from several European countries. Their analysis was based on a sample of 259 HEIs from 7 European countries across the period of 2001-2005. They conducted a twostage DEA analysis. The main conclusion was that only 5\% of HEIs were fully-efficient. Universities from Switzerland obtained the best efficiency scores (Wolszczak-Derlacz \& Parteka, 2011). Overall, the literature confirmed that technical inefficiency is a common phenomenon in higher education all over the world (Cunha \& Rocha, 2012).

\section{Method}

We decided to take a slightly different approach than most of the literature previously mentioned, that treated a university as a basic analytical unit. However, one could doubt the uniformity of production technology at a university with many different faculties. Such uniformity is an important assumption in using DEA, which drew its origins from the economic concept of production function, in which production technology means the relationship between inputs and outputs (Fried, Lovell, \& Schmidt 1993). Carlton and Perloff (2005) noted that, "knowing the cost function of a firm and knowing its technology are equivalent" (p. 32). For example, in the case of the Warsaw University, the costs of teaching one student at the Faculty of Physics is 11-times higher than at the Faculty of Journalism and Political Sciences (Wilkin, 2009). Thus, it is clear for us, that efficiency should be measured rather on the faculty than on the whole university level.

After the political and economic transition, the Polish higher education system faced a rapid growth measured by the number of students (about $450 \%$ growth during the first two decades after transition). It was forecasted that until 2020, the number of students will be reduced by $35 \%$. Privately held higher education institutions established after transition, which achieve about one third share in total students' number in Poland, played an important role in this growth (Pietrzak, 2013). The areas of teaching at private universities are dominated by social sciences (economics, management, law, political sciences, sociology etc.). Thus, social sciences are the main field of rivalry between privately and publicly held HEIs. This competition should be growing because of the predicted falls in demand. It seems interesting to assess the efficiency of social sciences faculties affiliated at public higher education institutions. There are 150 such faculties in Poland. The data from 33 of them could be collected. We investigated their efficiency using the DEA method.

DEA is a non-parametric mathematical programming approach for measuring relative efficiencies of comparable Decision Making Units (DMUs) with respect to multiple inputs and outputs. Charnes, Cooper, and Rhodes (1978) described DEA as a "mathematical programming 
model applied to observational data that provides a new way of obtaining empirical estimates of relations, such as the production functions and/or efficient production possibility surfaces, that are cornerstones of modern economics" ( $p$. 429-444). The DEA model may be presented mathematically in the following manner (Cooper Seiford, \& Tone, 2007, p. 23):
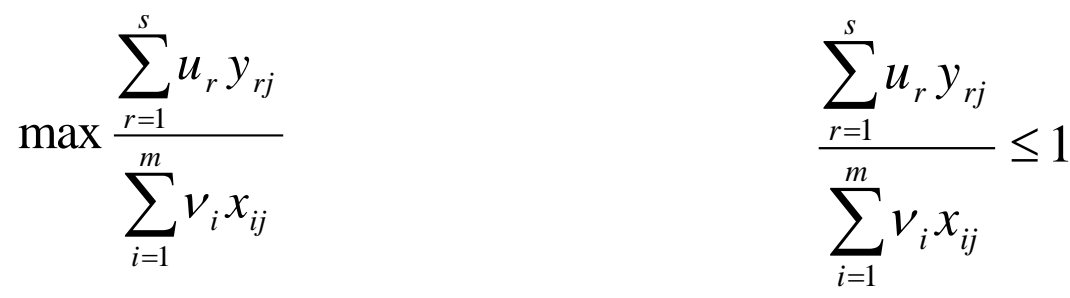

$$
u_{r}, v_{i} \geq 0
$$

where:

$s$ - quantity of outputs, $m$ - quantity of inputs, $u_{r}$ - weights denoting the significance of respective outputs, $v_{i}$ - weights denoting the significance of respective inputs, $y_{r j}-$ amount of output of $r$-th type $(r=1, \ldots, \mathrm{R})$ in $j$-th object, $x_{\mathrm{ij}}$ - amount of input of $i$-th type $(i=1, \ldots, \mathrm{I})$ in $j$ th object; $(j=1, \ldots, \mathrm{J})$.

In the DEA model $m$ of inputs and $s$ of diverse outputs come down to single figures of "synthetic" input and "synthetic" output, which are subsequently used for calculating the object efficiency index. The quotient of synthetic output and synthetic input is an objective function, which is solved in linear programming. Optimized variables include $u_{r}$ and $v_{\mathrm{i}}$ coefficients, which represent weights of input and output amounts, and the output and input amounts are empirical data (Cooper et al., 2007).

By solving the objective function using linear programming it is possible to determine the efficiency curve called also the production frontier, which covers all the most efficient units of the focus group. The graphical presentation of the efficiency curve is possible for models: 1 input and 1 output, 2 inputs and 1 output, or 1 input and 2 outputs. In the case of multidimensional models the curve equivalent incorporates a few fragments of different hyperplanes linked to each other. Objects are believed to be technically efficient if they are located on the efficiency curve. Objects technically efficient achieve the best possible combination of their effects (production) to the input. In other words, their efficiency index equals 1, which means that for example in the model focused on input minimization, there is not any other more favourable combination of inputs allowing to achieve the same outputs (Coelli, Prasada Rao, O'Donnell, \& Battese 2005). However, if they are beyond the efficiency curve, they are technically inefficient (their efficiency index is below 1). The efficiency of the object is measured against other objects from the studied group and is assigned values from the range $(0,1)$. The DEA models measure the efficiency of a Decision Making Unit relative to similar DMUs in order to estimate a 'best practice' frontier. It means that the DEA method measures relative efficiency (Charnes et al., 1978).

The DEA models may be categorized based on two criteria: orientation and type of returns to scale. Depending on the model orientation, the calculations of efficiency focused either on the input minimization or on the output maximization are made. Taking into account the type of 
returns to scale, the two models are distinguished: the Charnes-Cooper-Rhodes (CCR) model (Charnes, Banker, \& Rhodes, 1978) and the Banker-Charnes-Cooper (BCC) model (Banker, Charnes, \& Cooper, 1984). The CCR model is built on the assumption of constant returns to scale: this means that inputs and outputs are linked in a strictly proportional manner. The CCR efficiency scores measure the overall technical efficiency (Technical Efficiency - TE), where TE for $\mathrm{P}$ object $=\mathrm{AP}_{\mathrm{C}} / \mathrm{AP}$ (Figure 1). The $\mathrm{BCC}$ model is an extension of the CCR model and allows for the fact that the productivity at the most productive scale size may not be attainable for other scale sizes at which a given Decision Making Unit is operating. Therefore, the BCC model estimates the pure technical efficiency of a DMU at a given scale of operation (Pure Technical Efficiency - PTE), where PTE for P object $=\mathrm{AP}_{\mathrm{V}} / \mathrm{AP}$ (Figure 1). The only difference between the CCR and BCC models is the convexity condition of the BCC model, which means that the frontiers of the $\mathrm{BCC}$ model have piecewise linear and concave characteristics, which lead to variable returns-to-scale (Coelli et al., 2005).

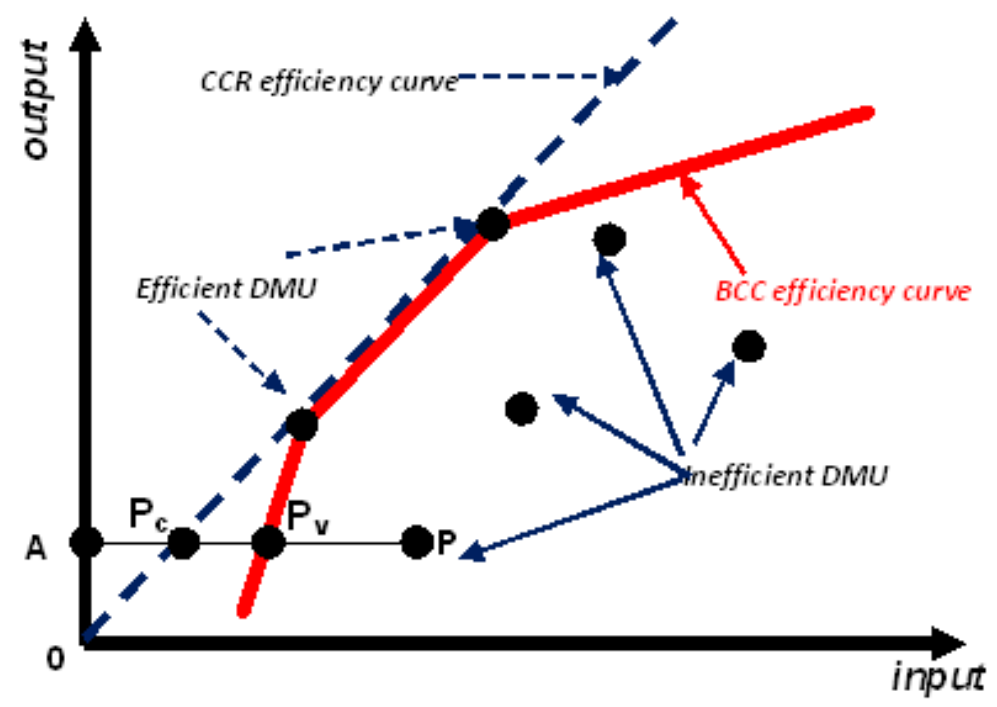

Figure 1. Efficiency according to the DEA method (model: 1 output and 1 input) Source: Coelli et al., 2005, p. 61

The key issue in our research study was the selection of inputs and outputs. As one can find in our review of efficiency studies of the higher education, the variables that are typically used as inputs are: the number of academic staff, the non-academic staff, the financial resources of the institutions, as well as their major expenditures. We followed these proposals and selected two variables as inputs:

- $\quad$ input 1: total number of researchers (i.e. academic staff),

- $\quad$ input 2: statutory grant (i.e. core financial resources received from governmental budget). 
The variables usually used as outputs in literature are: the total number of successful leavers (graduates), the number of publications in internationally/ nationally referred journals or number of $\mathrm{PhD}$ degrees. This research study partially followed those approaches. They generally mirrored the traditional view of the university and its role in the society, namely conducting scientific research and academic teaching. In literature such a view is called the Humboldtian or liberal model of the university (Leja, 2013). However, contemporarily an evolution towards the entrepreneurial model of the university can be observed. In such a model, the general mission of the university is enlarged and consists of three pillars not only research and teaching but also supporting the economic and social development (Leja, 2013). Such a view of the role of public higher education institutions is also emphasized in recent reforms of the law, which regulates public universities in Poland (Pietrzak, 2013). Thus, defining outputs we tried to take into account such an extended view of the public university mission:

- output 1: total number of students (reflecting the activity in teaching)

- output 2: total value of externally acquired funds like funds for R\&D work etc., as well as externally granted research projects (reflecting the activity in supporting the development of university's environment)

- output 3: number of publications (reflecting the activity in scientific work)

It is not common in Poland to fire academic staff except for immoral acts, the loss of mental competence etc. and as there is not a government strategy to reduce financing of universities, we assumed that the output-oriented model would be more appropriate than an input-oriented model. As the number of studied objects (faculties) was not high, we decided to use the CCR model (in the BCC model the number of efficient units is always higher than in the CCR model). In summary, this research study used the CCR output-oriented model and MS Excel 2007 and DEASolverPro were used to perform the calculations .

\section{Results}

The results of relative efficiency for 33 Faculties of Social Sciences are presented in Table 2. In the academic year 2013/2014, the analyzed Faculties of Social Sciences in Poland experienced the efficiency index from 0.41 to 1 (average 0.72 ). Nine faculties were fully efficient. The group of efficient Decision Making Units covered the following faculties: WZ(PCz), WNPiDz(UAMP), WSE(UAMP), WAiNS(PW), WNE(UW), WZ(PL), WPiA(UW), WPsycho(UW), WEiZ(UZ). Among the inefficient faculties the lowest rate of efficiency was observed in: WZ(PRIL) and WP-A(UAMP) (see Table 2). 
Table 2. Ranking of faculties

\begin{tabular}{|c|c|c|}
\hline ID & Faculty & $\begin{array}{l}\text { DEA } \\
\text { score }\end{array}$ \\
\hline WEiZ(UZ) & Faculty of Economics and Management (University of Zielona Góra) & 1,000 \\
\hline WPsycho(UW) & Faculty of Psychology (Warsaw University) & 1,000 \\
\hline WPiA(UW) & Faculty of Law and Administration (Warsaw University) & 1,000 \\
\hline $\mathrm{WZ}(\mathrm{PL})$ & Faculty of Management (Lublin University of Technology) & 1,000 \\
\hline WNE(UW) & Faculty of Economic Sciences (Warsaw University) & 1,000 \\
\hline WAiNS(PW) & Faculty of Administration and Social Sciences (Warsaw University of Technology) & 1,000 \\
\hline WSE(UAMP) & Faculty of Educational Studies (Adam Mickiewicz University in Poznań) & 1,000 \\
\hline WNPiDz(UAMP) & Faculty of Political Science and Journalism (Adam Mickiewicz University in Poznań) & 1,000 \\
\hline $\mathrm{WZ}(\mathrm{PCz})$ & Faculty of Management (Częstochowa University of Technology) & 1,000 \\
\hline WNE(SGGW) & Faculty of Economic Sciences (Warsaw University of Life Sciences) & 0,882 \\
\hline WPiA(USK) & Faculty of Law and Administration (University of Silesia in Katowice) & 0,853 \\
\hline WPiA(UWMO) & Faculty of Law and Administration (Warmian and Mazurian University in Olsztyn) & 0,825 \\
\hline WNE(UWMO) & Faculty of Economics (Warmian and Mazurian University in Olsztyn) & 0,810 \\
\hline WZ(UW) & Faculty of Management (Warsaw University) & 0,774 \\
\hline WPiA(UJK) & Faculty of Law and Administration (Jagiellonian University in Kraków) & 0,724 \\
\hline WNS(USK) & Faculty of Social Science (University of Silesia in Katowice) & 0,672 \\
\hline WZiKS(UJK) & Faculty of Management and Social Communication (Jagiellonian University in Kraków) & 0,667 \\
\hline WOiZ(PSG) & Faculty of Organization and Management (Silesian University of Technology) & 0,610 \\
\hline WSNSiR(UW) & Faculty of Applied Social Sciences and Resocialisation (Warsaw University) & 0,593 \\
\hline WEiNoE(USK) & Faculty of Ethnology and Educational Science (University of Silesia in Katowice) & 0,593 \\
\hline WDziNP(UW) & Faculty of Journalism and Political Science (Warsaw University) & 0,591 \\
\hline WPiP(USK) & Faculty of Pedagogy and Psychology (University of Silesia in Katowice) & 0,588 \\
\hline WP(UW) & Faculty of Education (Warsaw University) & 0,577 \\
\hline WRiT(USK) & Faculty of Radio and Television (University of Silesia in Katowice) & 0,562 \\
\hline $\mathrm{WZ}(\mathrm{PW})$ & Faculty of Management (Warsaw University of Technology) & 0,554 \\
\hline WNS(SGGW) & Faculty of Social Sciences (Warsaw University of Life Sciences) & 0,536 \\
\hline WPiA(UAMP) & Faculty of Law and Administration (Adam Mickiewicz University in Poznań) & 0,518 \\
\hline WSMiP(UJK) & Faculty of International and Political Studies (Jagiellonian University in Kraków) & 0,499 \\
\hline WNS(UAMP) & Faculty of Social Sciences (Adam Mickiewicz University in Poznań) & 0,493 \\
\hline WNS(UWMO) & Faculty of Social Sciences (Warmian and Mazurian University in Olsztyn) & 0,473 \\
\hline WPSiNoZ(UZ) & Faculty of Education, Psychology and Sociology (University of Zielona Góra) & 0,427 \\
\hline WP-A(UAMP) & Faculty of Pedagogy and Fine Arts (Adam Mickiewicz University in Poznań) & 0,418 \\
\hline WZ(PRIL) & Faculty of Management (Rzeszów University of Technology) & 0,407 \\
\hline
\end{tabular}

Source: own calculations based on: universities' annual reports

Based on the DEA method, benchmarks were defined for the inefficient faculties. On the basis of these benchmarks for inefficient faculties (Decision Making Units), it is possible to determine a combination of technologies that allows more results to be achieved with the same inputs. Calculations were made based on the values of coefficients of the linear combination of common technology. Based on these coefficients, it is possible to construct an optimal technology modelled on the inefficient faculties by defining benchmarks for them. For example, for WNE(SGGW) benchmarks would consist of WZ(PL), WSE(UAMP) and WEiZ(UZ). For $\mathrm{WNE}(\mathrm{SGGW})$ the following combination of technology is therefore optimal: $17,3 \% \mathrm{WZ}(\mathrm{PL})$ technology, 30,9\% WSE(UAMP) technology and 115,3\% WEiZ(UZ) technology. In order to be efficient, WNE(SGGW) should achieve the level of outputs shown in Table 3. 
Table 3. The results of the benchmarking analysis for Faculty of Economic Sciences at Warsaw University of Life Sciences - WNE(SGGW)

\begin{tabular}{|c|c|c|c|c|c|c|}
\hline & \multicolumn{3}{|c|}{ Benchmarks for WNE(SGGW) } & \multirow{2}{*}{$\begin{array}{l}\text { Projected output } \\
\text { for WNE(SGGW) }\end{array}$} & \multirow{2}{*}{$\begin{array}{l}\text { Present level of } \\
\text { WNE(SGGW) } \\
\text { outputs }\end{array}$} & \multirow{2}{*}{$\begin{array}{c}\text { Estimated } \\
\text { percentage } \\
\text { increase in the } \\
\text { outputs of } \\
\text { WNE(SGGW) }\end{array}$} \\
\hline & $\begin{array}{r}\text { WZ } \\
(\mathbf{P L})\end{array}$ & $\begin{array}{c}\text { WSE } \\
\text { (UAMP) }\end{array}$ & $\begin{array}{c}\text { WEiZ } \\
(\mathrm{UZ})\end{array}$ & & & \\
\hline $\begin{array}{l}\text { Output } 1 \text { - } \\
\text { number of } \\
\text { students }\end{array}$ & 1246 & 7917 & 2723 & $\begin{array}{c}0,173 \times 1246+0,309 \times \\
7917+1,153 \times 2723=5798\end{array}$ & 5117 & $13,32 \%$ \\
\hline $\begin{array}{l}\text { Output } 2 \text { - } \\
\text { externally } \\
\text { acquired } \\
\text { funds }\end{array}$ & 824937 & 611480 & 163440 & $\begin{array}{c}0,173 \times 824937+0,309 \times \\
611480+1,153 \times 163440= \\
519915\end{array}$ & 458790 & $13,32 \%$ \\
\hline $\begin{array}{l}\text { Output } 3 \text { - } \\
\text { number of } \\
\text { publications }\end{array}$ & 258 & 371 & 286 & $\begin{array}{c}0,173 \times 258+0,309 \times \\
371+1,153 \times 286=489\end{array}$ & 356 & $37,32 \%$ \\
\hline $\begin{array}{l}\text { The values of } \\
\text { coefficients } \\
\text { of the linear } \\
\text { combination } \\
\text { of common } \\
\text { technology } \\
\text { for inefficient } \\
\text { WNE } \\
\text { (SGGW) }\end{array}$ & 0,173 & 0,309 & 1,153 & & & \\
\hline
\end{tabular}

Source: Calculations based on universities' annual reports

The resulting outputs are far above those achieved in the WNE(SGGW). As a result, the faculty could be classified as efficient by achieving $13 \%$ more students, increasing externally acquired funds by $13 \%$, and publishing $37 \%$ more papers. Table 4 shows potential changes in outputs in the set of inefficient faculties. The results suggest that inefficient faculties could improve their efficiency in all output variables. Thus, deans should concentrate their efforts on enhancing the performance by reaching the indicated growth effects (Table 4), while using the existing level of inputs (academic staff and statutory grant) to reach a maximum of "production capacity". 
Table 4. Estimated percentage increase in the outputs of individual departments, which would improve the efficiency of departments using current inputs such as academic staff and statutory grant

\begin{tabular}{|c|c|c|c|}
\hline \multirow[b]{2}{*}{ DMU } & \multicolumn{3}{|c|}{ Projections } \\
\hline & $\begin{array}{c}\text { Output } 1 \\
\text { (number of students) } \\
\end{array}$ & $\begin{array}{c}\text { Output } 2 \\
\text { (externally acquired funds) }\end{array}$ & $\begin{array}{c}\text { Output } 3 \\
\text { (number of publications) } \\
\end{array}$ \\
\hline WNE(SGGW) & $13,32 \%$ & $13,32 \%$ & $37,32 \%$ \\
\hline WNS(SGGW) & $86,42 \%$ & $889,27 \%$ & $162,71 \%$ \\
\hline WOiZ(PSG) & $64,01 \%$ & $64,01 \%$ & $64,01 \%$ \\
\hline $\mathrm{WZ}(\mathrm{PW})$ & $80,51 \%$ & $999,90 \%$ & $406,17 \%$ \\
\hline WZ(PRIL) & $145,51 \%$ & $145,51 \%$ & $145,51 \%$ \\
\hline WNS(UAMP) & $102,76 \%$ & $102,76 \%$ & $102,76 \%$ \\
\hline WP-A(UAMP) & $139,33 \%$ & $999,90 \%$ & $139,33 \%$ \\
\hline WPiA(UAMP) & $93,04 \%$ & $93,04 \%$ & $93,04 \%$ \\
\hline WPiA(UJK) & $38,10 \%$ & $38,10 \%$ & $38,10 \%$ \\
\hline WZiKS(UJK) & $49,95 \%$ & $76,71 \%$ & $49,95 \%$ \\
\hline WSMiP(UJK) & $100,56 \%$ & $100,56 \%$ & $100,56 \%$ \\
\hline WEiNoE(USK) & $68,71 \%$ & $68,71 \%$ & $68,71 \%$ \\
\hline WNS(USK) & $48,91 \%$ & $48,91 \%$ & $48,91 \%$ \\
\hline WPiP(USK) & $70,06 \%$ & $70,06 \%$ & $70,06 \%$ \\
\hline WPiA(USK) & $17,22 \%$ & $17,22 \%$ & $17,22 \%$ \\
\hline WRiT(USK) & $77,98 \%$ & $999,90 \%$ & $77,98 \%$ \\
\hline WNE(UWMO) & $23,44 \%$ & $615,53 \%$ & $239,52 \%$ \\
\hline WNS(UWMO) & $111,59 \%$ & $999,90 \%$ & $261,74 \%$ \\
\hline WPiA(UWMO) & $21,20 \%$ & $110,48 \%$ & $410,74 \%$ \\
\hline WDziNP(UW) & $69,31 \%$ & $69,31 \%$ & $69,31 \%$ \\
\hline WP(UW) & $73,33 \%$ & $73,33 \%$ & $73,33 \%$ \\
\hline WSNSiR(UW) & $73,71 \%$ & $68,57 \%$ & $68,57 \%$ \\
\hline WZ(UW) & $29,13 \%$ & $47,49 \%$ & $74,45 \%$ \\
\hline WPSiNoZ(UZ) & $134,30 \%$ & $352,46 \%$ & $134,30 \%$ \\
\hline
\end{tabular}

Source: Calculations based on universities' annual reports

\section{Concluding remarks}

Governments typically support higher education services because they are merit goods, which create positive externalities. Particularly in Europe, governments often fund public universities. One of the interesting methods of assessment of their efficiency is the Data Envelopment Analysis (DEA), which is growing in popularity in the research of public sector performance. Typically, the DEA studies in the higher education are concerned with a whole university as a Decision Making Unit (DMU), however, we believe that the proper unit of such an analysis should be a faculty. This empirical investigation of efficiency was conducted on the sample of 33 
faculties specialized in social sciences across many public HEIs in Poland. This research study based on the CCR output-oriented model noted that there are substantial differences in efficiency between analysed entities. Important inefficiencies were identified. Their elimination could contribute to the enhancement of the social welfare. We also defined benchmarks for inefficient HEIs and quantified the necessary gaps to be fulfilled in order to become fully efficient.

However, one should be aware of the limitations of our research study. Firstly, the selection of inputs and outputs to control performance at the universities is very difficult (McCormick \& Meiners, 1988). Secondly, we used one input and one output, which are expressed in value terms. The DEA method concerns technical efficiency, so inputs and outputs should be preferably expressed in natural/ technical terms. Nevertheless, our inputs and outputs set does not diverge from the sets used by many other authors in similar studies. Moreover, the DEA method has some limitations itself: the sensitivity of extreme observations or failures in the units referred as efficient, the sensitivity of the total number of inputs and outputs (the greater it is, the greater the probability to be efficient is). The last one was the reason why in the case of limited number of faculties in the sample, we decided to use the CCR model. Finally, one should be aware that DEA defines efficiency in a relative manner, so it could be the case that a unit on the frontier of efficiency is not very efficient, but others conduct even worse.

Thus, further studies are welcome. We suggest to follow our approach and to investigate efficiency at a faculty level rather than a university level. It would be interesting to make comparisons between faculties at public and private universities. Comparisons between faculties from different countries could be very fruitful as well. Finding another and a better set of inputs and outputs for efficiency models would be also highly desirable.

\section{References}

Abramo, G., D'Angelo, C., Pugini, F. (2008). The measurement of Italian universities' research productivity by a nonparametric-bibliometric methodology. Scientometrics, Vol. 76.

Ansoff, H. I. (1979). Strategic management. London and Basingstoke: Macmilan Press.

Athanassopoulos, A.D., Shale, E. (1997). Assessing the comparative efficiency of higher education institutions in the UK by the means of data envelopment analysis. Education Economics, 5(2).

Banker, R.D., Charnes, A., Cooper, W.W. (1984). Some models for estimating technical and scale inefficiency in data envelopment analysis. Management Science, 30.

Baran, J., Pietrzak, M., Pietrzak, P. (2015). Efektywność funkcjonowania publicznych szkół wyższych [Efficiency of public higher education institutions]. Optimum. Studia ekonomiczne [Optimum. Studies of economics], 76(4).

Bates, J.M. (1993). The efficiency of local education authorities, Oxford Review of Education. 19.

Begg, D., Fischer, S., Dornbusch R. (2014). Economics 9th edition. London-United States: McGraw-Hill. 
Bowden, E.V., Bowden, J.H. (2002). Ekonomia. Nauka zdrowego rozsądku [Economics. The science of the common sens]. Warszawa: Fundacja Innowacja.

Byrson, J.M., \& Alston, F.K. (2011). Creating Your Strategic Plan. A workbook for public and nonprofit organizations. San Francisco, CA: Jossey-Bass A Wiley Imprint.

Carlton, D.W., Perloff, J. M. (2005). Modern industrial organization. Boston: Pearson Addison Wesley.

Carroll K.A. (2004). Property rights and managerial decisions in for-profit, nonprofit, and public organizations. Comparative THEIry and Policy. Houndmills: Palgrave MacMillan.

Charnes, A., Cooper, W.W., Rhodes, A. (1978). Measuring the efficiency of decision making units. European Journal of Operational Research, 2(6).

Coelli, T.J., Prasada Rao, D.S., O’Donnell, C.J., Battese, G. E. (2005). An Introduction to efficiency and productivity analysis. New York: Springer.

Cooper, W.W., Seiford, L.M., Tone K. (2007). Data Envelopment Analysis, A comprehensive text with models, applications, references and DEA-Solver software. New York: Kluwer Academic Publisheres.

Cunha, M., Rocha, V. (2012). On the efficiency of public higher education institutions in Portugal: an exploratory study. FEP Working Papers, 468.

(2009). Ekonomiczno-finansowe uwarunkowania rozwoju szkolnictwa wyższego w Polsce [Economic and Financial Conditions of Development of Higher Education in Poland], ed. Wilkin, J., in: Polish Higher Education. The State, the Conditions and Prospects]. Warsaw: Wyd. Uniwersytetu Warszawskiego.

Färe, R., Grosskopf, S., Lindgren, B., Roos, P. (1992). Productivity changes in Swedish pharmacies 1980-1989. A non-parametric malmquist approach. Journal of Productivity Analysis, 3.

Ferlie, E., Musselin, C., \& Andresani, G. (2008). The steering of higher education: A public management perspective. Higher Education, 56.

Fried H. O., Lovell C. A. K., Schmidt S. S., (1993). The Measurement of productive efficiency techniques and applications. Oxford University Press: New York, Oxford.

Hollingsworth, B., Dawson, P., Maniadakis, N. (1999). Measurement of health care. A review of nonparametric methods and applications. Health Care Management Science, 3.

Jacobs, R. (2001). Alternative methods to examine hospital efficiency: Data envelopment analysis and stochastic frontier analysis. Health Care Management Science, Vol. 4.

Johnes, J. (2006). Data envelopment analysis and its application to the measurement of efficiency in higher education. Economics of Education Review, 25.

Kantabutra, S., Tang, J. C. S. (2010). Efficiency analysis of public universities in Thailand. Tertiary Education and Management, Vol. 16(1). 
Kaplan, R. S., \& Norton, D. P. (2008). The execution premium. Linking strategy to operations for competitive advantage. Boston MA: Harvard Business School Press.

McMahon, W.W. (1982). Externalities in edcucation. Faculty Working Paper, No. 877.

McCormick, R. E., Meiners, R. E. (1988). University Governance: A property rights perspective. Journal of Law \& Economics, 31

Mikušová, P. (2015). An application of DEA methodology in efficiency measurement of the Czech public universities. Procedia Economics and Finance, 25.

Monafared, M.A.S., Safi, M. (2011). Efficiency analysis of public universities in Iran using DEA Aapproach: Importance of stakeholder's perspective. Journal of Industrial and Systems Engineering, 5.

Nazarko. J., Šaparauskas. J. (2014). Application of DEA method in efficiency evaluation of public higher education institutions. Technological and Economic Development of Economy, 20(1), 25-44.

Niven, P.R. (2008). Balanced Scorecard Step-by-Step for Government and Nonprofit Agencies. Hoboken, NJ: John Wiley\&Sons Inc.

Paliszkiewicz, J., O. (2010). Scenariusze i strategie rozwoju szkolnictwa wyższego w Polsce i za granica [Scenarios and Strategies of Development of Higher Education in Poland and other Countries]. Retrieved January 25, 2016 from http://www.akademickiemazowsze2030.pl/Data/File/54.pdf

Parker, L.D. (2012). From privatised to hybrid corporatised higher education: A global financial management discourse. Financial Accountability \& Management, 28(3), 247-268.

Pietrzak, M. (2013). Potrzeba kontroli zarządczej w publicznych szkołach wyższych [The need of managerial control in public universities"]. In: E. Nowak, \& M. Nieplowicz (Eds.), Rachunkowość a controlling [Accounting and Controlling] (pp. 404-414). Wroclaw: Economic University of Wroclaw.

Pietrzak, M. (2014). Using the strategy map as a strategic communication tool in higher education: A case study of Warsaw University of Life Sciences. Online Journal of Applied Knowledge Management, 2(2).

Pietrzak, M., Paliszkiewicz, J., Klepacki, B. (2015). The application of the balanced scorecard (BSC) in the higher education setting of a Polish university. Online Journal of Applied Knowledge Management, 3(1).

Schimank, U. (2005). 'New Public Management' and the Academic Profession: Reflections on the German Situation. Minerva, 43.

Sun, S. (2004). Assessing joint maintenance shops in the Taiwanese army using data envelopment analysis. Journal of Operations Management, 22.

Tahar, S. (2013). Resource allocation in higher education in the context of new public management. Public Management Review, 15(5). 
Thanassoulis, E., Dunstan P. (1994). Guiding schools to improved performance using data envelopment analysis: An Illustration with Data from a Local Education Authority. Journal of the Operational Research Society, 45.

Taylor, B., Harris, G. (2004.). Relative efficiency among South African universities: a data envelopment analysis. Higher Education, 47.

Taylor, J., \& Bains, C. (2012). Performance management in UK universities: Implementing the balanced scorecard. Journal of Higher EducationPolicy and Management, 34(2).

Tirole ,J. (1988). The THEIry of Industrial Organization, Cambridge MA: The MIT Press

Warning, S. (2004). Performance differences in German higher education: Empirical analysis of strategic group. Review of Industrial Organization, 24.

Wilkesman, U., \& Schmid Ch. J. (2012). The impacts of new governance on teaching at Germany universities: Findings from a national survey. Higher Education, 63.

Wolszczak-Derlacz, J., Parteka, A. (2011). Efficiency of European public higher education institutions: a two-stage multicountry approach. Scientometrics, 89.

Worthington, A.C. (2001). An empirical survey of frontier efficiency measurement techniques in education. Education Economics, 9(3).

\section{Authors' Biographies}

Michal Pietrzak is a strategic management and performance measurement researcher and practitioner. He is a professor at Faculty of Economic Sciences at Warsaw University of Life Sciences - SGGW and a vice chairman of the committee responsible for the strategy of this university. His main areas of interest include industrial organization and competitive strategy, Balanced Scorecard, performance measurement, and recently strategic learning. His consultancy experience covers strategic analyses, strategy development, BSC implementation for automotive, energy, chemistry, professional services, municipal services, public agencies and universities.

Piotr Pietrzak is a performance measurement researcher. He is a $\mathrm{PhD}$ student at Faculty of Economic Sciences and a vice chairman of PhD student Union at Warsaw University of Life Sciences - SGGW. His main areas of interest include efficiency of public sector institutions, performance measurement, Balanced Scorecard.

Joanna Baran is a management and logistics researcher and practitioner. She is an assistant professor at Faculty of Economic Sciences at Warsaw University of Life Sciences - SGGW. She has published over 100 original papers. Her main areas of interest include efficiency of business and public entities (Data Envelopment Analysis, production function), finance analysis, logistics. Her consultancy experience covers strategic analyses and logistic enterprises development. 